\title{
Four Inclinations in Human Nature: Evaluated in Light of Al-Ghazzâlî's Concept of the Heart
}

\author{
Hatice P. Kemahli ${ }^{1}$ \\ Marmara University
}

\begin{abstract}
This article examines human nature and behavior through the lens of Al-Ghazzâlî's concept of the heart (AR: qalb). The root of the Arabic word for heart means "turn, change." A great thinker of Islamic civilization, Ghazzâlî held the heart as the spiritual center of man and that whatever occurs inside it manifests itself in the outside world. Therefore, a human being attempting to know himself must first observe the emotions and minute details in the inclinations of their heart. Ghazzâlîs "heart" experiences continual change consequent to myriad forces from the physical (AR: jismânî) and the spiritual (AR: rûhânî) worlds. Therefore, it is highly difficult to observe and understand this changeable spiritual organ. Ghazzâlî's heart is the center of sentience and is home to a range of base instincts and inclinations, which Ghazzâlî terms the attributes of the heart, dividing them into four fundamental categories: animalistic/lust, ${ }^{2}$ predation/anger, ${ }^{3}$ divine, ${ }^{4}$ and satanic ${ }^{5}$ attributes. Ghazzâlî states that since these powers affect and change human nature and direct behavior, they can lead to degeneration. ${ }^{6}$ Likewise, they can potentially provide an opportunity for human development and safeguard one's progeny when they are used as directed by the faculty of reason (AR: 'aql).
\end{abstract}

Keywords

Ghazzâlî • Spiritual psychology • Concept of the heart • In clination $\bullet$ Impulse $\bullet$ Lust $•$ Anger

İnsan Doğasının Dört Temel Eğilimi: Gazzali'nin Kalp Kavramı Üzerinden Değerlendirilmesi

$\ddot{O} \mathbf{z}$

Bu makalede insan doğası ve davranışlarının altında yatan temel eğilimlerin analizi, İslam Medeniyetinin büyük düşünürlerinden biri olan Gazzali'nin kalp kavramı üzerinden ele alınmıştır. Gazzali’ye göre kalp, insan maneviyatının merkezi terimidir ve içerisinde her ne hâsıl olursa bunu dışarıya sızdırmaktadır. Bu sebeple kendini anlamaya ve tanımaya çalışan insan, önce kalbi hisleri ve yönelimlerindeki incelikleri dikkatlice gözlemlemelidir. Gazzali kalbin, cismani âlemden ve ruhani âlemden çeşitli güçler vasıtasıyla gelen etkiler nedeniyle sürekli olarak değişime uğradığını ifade etmiştir. Bu sebeple etimolojik kökeni "dönme, değişme" anlamına geldiği bilinen kalbin gözlemlenmesi ve anlaşılmasının oldukça güç bir iş olduğunu belirtmiştir. Gazzali’ye göre insan duyarlılığının merkezi kabul edilen kalp, birçok temel güdü ve eğilimi yapısında barındırmaktadır. Bu eğilimler Gazzali'de kalbin sıfatları olarak isimlendirilmiş; hayvaniyet/şehvet ve yırtıcılıktır/öfke , rabbaniyet , şeytaniyet olarak dört temel unsura ayrılmıştır. Gazzali, eserlerinde insan doğasını etkileyen ve davranışlarını yönlendiren bu güçlerin çeşitli tesirlerle değişime uğrayarak tefessühlere sebep olabileceğini bildirdiği gibi aklın yönetiminde kullanıldığında insanın gelişimine ve neslin korunmasına imkân sağlayacağını ifade etmiştir.

\section{Anahtar Kelimeler}

Gazzali • Manevi psikoloji • Kalp kavramı • Eğilim • Dürtü • Şehvet • Öfke

\footnotetext{
1 Correspondence to: Hatice Pınar Kemahl1, Department of Educational Sciences, Marmara University, Istanbul 34722 Turkey. Email: haticepinarozdemir@gmail.com

2 Šahwah/Haywâniyyah (Arabic): Sexuality, excessive desire. Both concepts are used in this work.

3 Ğadab (Arabic): Aggressiveness. Both concepts are used in this work.

4 Rabbâniyyah (Arabic): Arrogance/Narcissism.

5 Šaytâniyyah (Arabic): Craftiness/Manipulation. Sometimes this notion is expressed with the term devilry in this work.

6 Tafassuh (Arabic): When a person, society, etc. deteriorates through the loss its particular features and qualities, to rot.

Citation: Kemahl, H. P. (2017). Four inclinations in human nature: Evaluated in light of Al-Ghazzâli's concept of the heart. Spiritual Psychology and Counseling, 2, 9-30. http://dx.doi.org/10.12738/spc.2017.1.0016
} 
Behavioral science is a branch of science affected by scientific findings, historical developments, and philosophical currents (Karaırmak, 2004). Beginning in the period of enlightenment following the dark ages in the $17^{\text {th }}$ and $18^{\text {th }}$ centuries, Western science and culture began focusing on opening the hidden doors of the human mind using rational methods. Not only was this very effort to obtain perfect knowledge and the rise of psychological theories founded on a positivist paradigm using a reductionist approach to reach objectivity and in which understanding took up the generalization of findings dominant centuries prior to the European enlightenment, so too were a variety of recommendations on the makeup and behaviors of human beings made centuries prior to this specific period by thinkers living in different geographical areas. At the beginning of the $20^{\text {th }}$ century, the rising postmodern understanding began to offer significant objections to the fundamental presumptions held by the exponents of modernist thought, thereby offering an alternative to the previously dominant positivist paradigm (Yıldırım \& Şimşek, 2011). This began a transformation from a single truth to multiple realities, from individual knowledge to the mutual construction of knowledge, from a world analyzed objectively to a world constructed communally, and from a language seen as the carrier of knowledge to a language constructing local truths (Gergen \& Collage, 2001). This new paradigm made apparent not only the need for the universality of both the zeitgeist's ${ }^{7}$ (Schultz \& Schultz, 2007) and socio-psychological theories developed under the influence of a dominant culture context to be questioned, but also the need for alternative discourses to be brought to the scientific stage. Therefore, this study creates a platform to discuss new concepts and theories of people with similar psycho-social dynamics within their own system of values by exploring Ghazzâlî's analyzes on the makeup of human beings and his recommendations related to their behaviors, as he is a philosopher from within the Eastern-Islamic thought system offering alternative discourse on such issues.

\section{Ghazzâlî’s Life}

Ghazzâlî is undoubtedly one of most noteworthy Islamic thinkers to have appeared within the more than 14 centuries' worth of Islamic thought and ideas. Ghazzâlî was born in 450AH/1058AD in Tûs, a city located in the northeastern part of present-day Iran (Haque, 2004). His father, Muhammad, who worked as a wool spinner, was interested in and maintained relations with scholars of his era and individuals who strove to continue the thriving sûfî tradition (Uludağ, 2000). He entrusted Ghazzâlî to one of his close sûfî friends just before dying so that he might not be deprived of an education. Ghazzâlî spent his childhood and adolescence in the cities of Tûs, Gorgan, and Nishapur receiving a religious education in a wide variety of areas from distinguished scholars of his time. His teacher in Nishapur stated that "Ghazzâlî is

$\overline{7 \text { Zeitgeist (German) }}$ : The way of thinking and feeling of a specific period (Schultz \& Schultz). 
a deep sea" (Orman, 2000). As a result of his high achievement, keen insight, and ability to comprehend and master difficult issues, he caught the attention and won the favor of top state officials in a short amount of time and was appointed as the head professorship at Al-Nizamiyyah Madrasah of Baghdad (Watt, 1963). His work here, the lessons he taught, and the works he wrote raised him to the peak of his success, rendering the most famous scholar of his era (Attaran, 2015).

Despite the fame and success that he had attained at such a young age, Ghazzâlî left his position and Baghdad altogether to research true knowledge. During his near 10-year life of seclusion ${ }^{8}$ during which period he also performed the Hajj pilgrimage (Watt, 1963), Ghazzâlî advanced in the field of Sufism/mysticism (AR: tasawwuf) (Orman, 2000) and wrote his most well-known and greatest work, Ihyâ' u Ulûmi'd-Dîn (Revival of Religious Sciences). Later, at the request of top state officials, he returned to Nishapur, where he busied himself with education and scientific pursuits; yet his time in Nishapur ended shortly thereafter (Nakamura, 2001). Yearning for a return to a life of seclusion, he finally left his position in official education and returned to his city of birth, Tûs, where he had a madrasah constructed next to his house to teach Islamic jurisprudence (AR: fiqh) and sufiyyah. ${ }^{9}$ Spending the final period of his life teaching, organizing discussion circles, reading the Qur'ân, occupying himself with hadîth knowledge, and worshiping God (Çağrıc1, 1996), Ghazzâlî died in 1111 AD and was buried in a graveyard in the town of Taberan in Tûs (Hozien, 2011)

Dedicating his life to learning and teaching, Ghazzâlî's works on such religious sciences of Islamic jurisprudence (AR: fiqh), discourse (AR: kalâm), philosophy, politics, mysticism (AR: tașawwuf), morality, and rational knowledge (Fahri, 2008) are among the more prominent works in the history of science and thought (Attaran, 2015). Undoubtedly, analyzing the value and of quality of man holds an important place in Ghazzâlî's mind. According to him, human beings are endowed with a range of tools representing every single step from the lowest to the highest rank in the entire hierarchy of existence. By using these abilities in an appropriate and measured manner, man is able to attain a distinguished place among all that exists (Haque, 2004), due to his spiritually transcendental nature in comparison to other beings. One of the secrets to Ghazzâlî's continued prominence in the field of knowledge spanning from ancient history until today is undoubtedly due to that he does not neglect man's spiritual dimension and psychological makeup in his works (Çağrıcı, 2013).

8 İnziwâ (Arabic): Deliberately staying away from worldly affairs in order to reach a level of spiritual maturity, the process of retiring to an isolated corner away from other human beings (Akay, 2004).

9 Sûfiyyah: Name of a specific Islamic/Sufi mystical order [the name given to a group engaged in Sufi-related knowledge] (Uludağ, 2002). 


\section{Ghazzâlî's Concept of the Heart}

Ghazzâlî holds that man consists of two things (Ghazzâlî, trans. 2004). The first is our apparent (AR: zâhirî) form, our body, whereas the second is our spiritual side, which consists of our character (Langulung, 2002). Taking man as a whole, the most important concept that Ghazzâlî emphasizes while explaining the nature of man is his spiritual (AR: ma nawî) dimension, for it contains man's psychological dynamics (Othman, 2014). Ghazzâlî analyzes man's spiritual dimension in the context of the "heart" (qalb), "soul/inner self" (rûh), "desire-natura/ego" (nafs), and "intellect/mind" ('aql) (Ghazzâlî, trans. 2004; Haque, 2004; Haque \& Mohamed, 2009; Othman, 2016; Skinner, 2010). However, the differences in meaning and the details of the limits of the concepts composing our spiritual aspect are not clearly stated in the section " 'Ajâ' 'ib 'il-qalb" (Peculiarities of the Heart) of his work, Ihya' $u$ 'Ulumi'd-dîn, which instead emphasizes the importance of knowing their functions and qualities (Ghazzâlî, trans. 1994).

In his explanation of man's spiritual makeup, Ghazzâlî evaluates the heart as being a superior organ that encompasses all the other concepts, rendering it the key concept (Haque, 2004). Man's heart, in its most apparent meaning, in a biophysiological sense, carries great importance in its being the organ that circulates blood (Ghazzâlî, trans. 1994; Shah, 2015). Likening it to the light emitted from a lamp (Akçay, 2005), the heart is described as the place where the rûh settles (Ames, 2013), which in psychological literature is conceptualized as the soul (Sherif, 1975). The soul changes, develops, and transforms the ego, and can also be defined as the inner self (Skinner, 2010). According to Ghazzâlî, the heart is the soul's realm (Akçay, 2005). In a concrete sense, just as this heart is found in human beings, so too is it found in animals, and even in the dead. In its second meaning however, the heart indicates an intangible organ invisible to the eyes that has a permanent relation to its bio-physiological side (Shah, 2015). And according to Ghazzâlî, it is this heart, in this spiritual/psychological sense that is the very essence of human beings (Othman, 2014). In his works, Ghazzâlî sometimes even prefers to use the term self for the concept of the heart (Umaruddin, 2003).

Ghazzâlî did not attempt to examine the heart in a biological sense, stating that this was a matter related to the medical sciences. Likening the fine link between the heart's biological and psychological aspects to the relation between an object and its colors or to a captain and his ship, Ghazzâlî explains his understanding of the heart's makeup and its inclinations using a variety of examples (Ghazzâlî, trans. 1994).

According to Ghazzâlî, the heart is the most important faculty in pursuing knowledge, comprehending the subtleties of the tangible world (AR: 'âlemu'š-šahâdah), and researching reality (Çağrıc1, 2013). Possessing properties of the spiritual world (AR: 'âlemu'l-ğayb), the heart is a spiritual core (AR: jawhar) specially created by Allâh 
(swt). For it is by means of the heart and its qualities and abilities that man may attain his superior position among all beings (Sherif, 1975). Ghazzâlî explains that man's faculty of reason (AR: 'aql), which is used to increase humanity's value and which is described as distinguishing man from other beings, is located in the heart (Umaruddin, 2003). Ghazzâlî viewed man's faculty of reason as a filter safeguarding him from the harmful thoughts of his environment and nature as well as from his own harmful impulses (Ghazzâlî, trans. 2004). Moreover, man's faculty of reason is the director of the mechanism that made decisions concerning his behaviors and preferences. Ghazzâlî grouped this spiritual faculty (AR: laṭ̂fah) qualitatively, rated it according to its functions (Erdem, 2011), and sometimes considered it as an aspect of man's heart that performed regulatory functions (Haque, 2004).

Ghazzâlî held that it was the heart that experienced such feelings ranging from happiness to hopelessness as a result of whether the possessor of the heart performed or did not perform those actions for which he had been made responsible (Çağrıc1, 2013). While explaining the importance of the heart in his work Minhaj'ul- âbidin ${ }^{10}$ (trans. 2007), Ghazzâlî emphasizes that the heart is expressly different than other organs. His statement "I considered the state of the heart and saw five peculiarities not found in other organs," (p. 128) touches on the points described below.

According to Ghazzâlî, it is in the heart that two opposing poles, these being man's actions and thoughts, lie, stating that it is in the heart that the clash between doing and abstaining from an action takes place. As such, the heart finds itself in a strategic position where the inclinations found within it collide. Ghazzâlî informs us that since the heart is open to stimuli from both within and without it, both harmful thoughts and creative ideas encroach on and affect it. Describing the heart as being more energetic than a boiling cauldron atop a fire, Ghazzâlî states that the fact that the thoughts, feelings, and inclinations inside the heart change so rapidly reflects on a person's behaviors. Ghazzâlî also states that since the various potential spiritual sicknesses resulting from changes in the impulses, fruitless ideas, and delusions (AR: awhâm) experienced in the heart are both intangible and invisible to the physical eye, it is not only difficult to treat them, but also to diagnose them. As such, he asserts that the heart can only be successfully treated by spending a long period of time and a great deal of effort on it.

In explaining the above-mentioned attributes of the heart, Ghazzâlî emphasizes the importance of constructing a model in the reader's mind using a variety of metaphors and symbolic language (Ames, 2013; Watt, 2000). A few examples on the state and condition of the heart from his work Kimiya-i Sa $a ̂ d a h^{11}$ (trans. 2000) are presented below:

10 Eng: Path of the Servant

11 Eng: Alchemy of Happiness 
"The heart is like the sultan of a city, and the body is the city. The hands, feed, and other organs are the city's artisans, the heart's inclinations are its officials, and one's faculty of reason, endowed with knowledge and will, is the sultan's vizier" (p. 18).

"The five senses as well as one's faculties of imagination (AR: khayâl), illation (AR: wahm), memory, the mind's eye (AR: takhayyul), sympathy, and cognition (AR: idrâk) are the body's soldiers. Located in the brain, each one of these faculties has its own particular duty. These internal and external soldiers are at the heart's command. The tongue speaks and the hand moves as soon as they are commanded to do so" (p. 16).

"The sultan has need of these faculties because it is only with them that his domain may be managed effectively. In short, in order for these jobs to be performed, there must be a close link between the heart and the body" (p. 18).

“... however, in the event that the officials fail to perform their duties in a proper manner, the domain will fall into disorder, thereby resulting in the sultan falling into despair" (p. 18).

\section{Changes of the Heart According to Ghazzâlî}

Emphasizing that the Arabic word for heart (qalb) is derived from the etymological root meaning "to turn/to change," Ghazzâlî states that it is impossible for the heart to remain unaffected by influences assailing it from both the physical and spiritual realms. Ghazzâlî explains in Ihya'u 'Ulûmi'd-dîn (trans. 1994) that due to its being permanently open to internal and external influences, the heart, with its various inclinations, is open to change.

"The heart may be resembled either to a dome through whose doors its many states (AR: ahwâl) seep inward, to a target being shot by arrows from all sides, or to a set of mirrors that infinitely reflects an image placed in front of it” (p. 2241).

Ghazzâlî explains that man is completely surrounded by a myriad of physical and spiritual beings (Haque, 2004) able to enter into his heart through the facets of his temperament (AR: mizâj) and creation (Azadpur, 2003). A mark is left on the heart whenever it is subject to any type of stimulus. When a person sees, learns, or feels something, some of the heart's inclinations begin to mobilize, others weaken in intensity, and still others group together, becoming even stronger. As a result of all of these that state (AR: hâl) sometimes transforms into action and other times continues in the form of imaginations, feelings, or thoughts, changing from one form to another and thereby causing the heart to change from one state to another (Ghazzâlî, trans. 1994).

According to Ghazzâlî, of the windows opening up onto the heart, the first consist of the sense organs of sight, hearing, touch, smell, and taste (Shah, 2015) along with his cognitive powers of imagination, scruples, the mind's eye, and thought, ${ }^{12}$ through

12 Analyst Reason/Bahtî 'Aql: The first type of the faculty of reason to appear according to Ghazzâlî. Ghazzâlî expresses that included in it are such cognitive strategies as imagination, memory, and thought, further stating that it is not possible to understand the physical world with this type of reason (Bolay, 2013). 
which vehicles beings existing in the physical world turn to in order to enter the heart (Bolay, 2013). Ghazzâlî also explained that the most important external factor on the environment is the human being, who is himself affected by the conditions in which he lives, the circumstances of his era, the period in which he lives, and the area in which he was born and raised (Ghazzâlî, trans. 2000). Ghazzâlî also asserted that society also exerts an influence on the inclinations intrinsic in man's nature and that man's feelings, thoughts, and behaviors are in a constant state of interaction with these inclinations (Ghazzâlî, trans. 2007).

Ghazzâlî holds that, just as it is in the physical world, it is possible for the heart to experience change by establishing a relation with the spiritual (AR: rûhânî) world using such means as personal insight (AR: bașirah), power of discernment (AR: farâsah), and intuition (AR: kašîf) ${ }^{13}$ (Bolay, 2013; Shah, 2015) and by being filled with elements from the spiritual world (İnam, 2000). Furthermore, a strong relation exists between these two worlds (Aydınl1, 2000). Ghazzâlî expounds on this in Kimiya-i Sa 'âdah:

"The heart has two doors. One is the spiritual/unseen (AR: malakût) world and the other is the physical/tangible world" (p. 24).

According to Ghazzâlî, the second window opening up onto the heart is the spiritual (AR: rûhânî) domain. One of the functions of the soul (AR: rûḥ), also called the inner self, in this domain is to transform inspiration (AR: ilhâm) and images into comprehensive thoughts and visions (AR: tamâtîl) by means of dreams and imaginations. This reality carries a similar quality to Jung's works on archetypes. The basic aim in Jung's therapy is to reach this closed-off area of the ego (Skinner, 2010). Ghazzâlî explains that it is wrong to think that the states affected by the inclinations of the heart stemming from the spiritual world are inaccessible without sleeping or before dying, recommending that following a spiritual path and methods that include forgoing physical pleasures and eating past only what is needed to survive (AR: riyâdah), ${ }^{14}$ reflection (AR: tafakkur), ${ }^{15}$ remembrance (AR: dikr),${ }^{16}$ and introspection (AR: murâqabah) ${ }^{17}$ in order to reach this state (Ames, 2013; Azadpur, 2003; Shah, 2015). Since the period designated by philosophers and scholars as the

13 Intuitive Reason/Hadțî 'Aql: The second type of the faculty of reason to appear, according to Ghazzâlî, in which personal insight, discernment, and intuitive abilities exist. With this type of reason, it is possible to transcend into the metaphysical realm. Here the concepts of reason, heart, and soul are used as synonyms (Bolay, 2013).

14 Riyâdah: Continuous and regular efforts spent to discipline oneself (AR: nafs) to progress on a spiritual journey (Akay, 2004).

15 Tafakkur (Arabic): Deep thinking done to comprehend something (Akay, 2004).

16 Dikr (Arabic): To make mention, say, internal speech, read to oneself, remember. Also includes the meaning of worship and prayer (Akay, 2005).

17 Murâqabah (Arabic): When a person monitors his own spiritual dimension (Akay, 2004). 
field of post-traditional development (Corsini \& Wedding, 2011), scientists striving to give meaning to man's existence have been obliged to enter into the spiritual realm of transpersonal approaches, mythology, and tasawwuf, feeling the need to delve into such spiritual abilities, analyzes, and methods as transcendental experiences, meditation, dreams, mystical consciousness, and active imagination (Hermansen, 2001; Merter, 2014; Parsons, 2013).

Ghazzâlî strongly emphasized the importance and value of seeing the faculty of reason as having the power to control the heart's inclinations, due to its ability to make a variety of mental judgments and comparisons related not only to empirical knowledge obtained using human senses and cognition, but also to metaphysical propositions using personal insight and power of discernment (Erdem, 2012). By itself, however, the faculty of reason is insufficient to conceptualize the metaphysical world, with Ghazzâlî stating that by only using reason to solve metaphysical issues, one reaches contradictory conclusions. (Bolay, 2013; Kukkonen, 2012). For healthy development, Ghazzâlî states that when the inner self (AR: rûḥ) within the heart is supported by reason, a dynamic relationship is created in which the two organs work together to direct the person. The relation between the characteristics of a person's reason and his soul (AR: rûh) is classified according to that person's stage of spiritual development. In his investigations, it can be seen that while man's makeup is subject to a strict division in western psychology, this is not the case in the Islamic tradition (Skinner, 2010). The concept of reason (AR: 'aql) is used in this study according to the definitions and qualifications laid out by Ghazzâlî without these definitions and qualifications being discussed in detail, due to the constraints of the research topic.

\section{Four Fundamental Inclinations in Man's Nature}

According to Ghazzâlî, man's makeup is composed of four very different fundamental inclinations coming together in a single being (Haque, 2004). Ghazzâlî asserts that the essence of man's behaviors and attitudes depends on these four fundamental sources of motivation (Cheraghi, 2012), stating that man's heart resembles a mirror encompassing all of these effective attributes. These represent man's base instincts as well as the fundamental elements of man's nature. According to Ghazzâlî, the four attributes found in the heart are (i) animalism/lust, (ii) predation/ anger, and (iii) divine and (iv) satanic attributes (Ghazzâlî, trans. 1994; Shah, 2015).

Following Islamic tradition, Ghazzâlî uses the word nafs $^{18}$ for these sources of motivation, themselves being equivalent to a sort of energy containing man's base

18 Nafs is an Arabic word that although literally means "self," has a usage similar, though not exactly the same, to the concept of "the flesh" in Christian theology. It is different from the word "anâ," which is equivalent to the pronoun I or ego as in western psychology. The Arabic root for nafs is related to such words as "breath" and "breathing." 
instincts and primitive desires (Çamdibi, 2014). Ghazzâlî sometimes uses the word nafs to indicate a person's ego/personality, whereas other times he uses it to mean ego consciousness (Haque \& Keshavarzi, 2014), stating that based on the ability to control these attributes, there are three nafs categories /levels of ego consciousness (Umaruddin, 2003). Striving for continued survival, the first and most primitive level of ego consciousness is called nafsu'l-ammârah (the lower self). ${ }^{19}$ At this level, the faculty of reason has very little control over the four abovementioned attributes, which are themselves without restriction or regulation. The second level of ego consciousness is called nafsu'l-lawwâmah (the self-reproaching self), at which stage the faculty of reason attempts to resist and control these primitive desires and impulses. The third level of ego consciousness is called nafsu'l-mutma innah (the peaceful self-holistic self). At this level, the primitive impulses submit to the authority of reason, thereby causing the person to attain both freedom and peace of mind and soul (Haque, 2004; Langgulung, 1991; Skinner, 2010).

Ghazzâlî states that each person has his own unique blend of the aforementioned attributes (Haque, 2004) and that they take root according to that person's personality. Although all four of these inclinations are present in every person, some of them are stronger than others, depending on that person's personal characteristics as well as one the conditions and time in which he lives (Ghazzâlî, trans. 1994). That influences from the physical and metaphysical world have the power to cause change in these sources of motivation has already been discussed in detail. Just as according to the nature of the change in question, disorders in man's nature and a variety of social problems may result, so too can these changes cause knowledge and willpower to increase, as well as other forms of human development.

It is widely held that no one before Freud emphasized the importance of either the direct or indirect effects that subconscious impulses have on man's emotions and thoughts (Schultz \& Schultz, 2007). Yet Ghazzâlî explained how these inclinations can cause changes to a human being's behavior and personality traits (trans. 2000, p. 21).

You have learned that these four powers are present in your own existence. As such, control your own thoughts and behaviors so that you might see just what the inclinations that lie beneath your behaviors are. You must know for certain that in every one of your actions, a number of your heart's qualities and their effects become manifest that act together with you. For perfect morality materializes through controlling these four elements.

19 Nafsu'l-ammârah literally means "the commanding self," as it commands to do bad. Its full version is nafsu'l-ammârah bi 's-ŝ́' and is revealed in the Qur'an in chapter 12, verse 53. 


\section{Animalistic/Lust Inclination}

According to Ghazzâlî, the first of these attributes in man's heart are appetite (AR: ištiyâq) and lust (AR: šahwah) (see footnote 3). Since the power of lust exists not only in human beings, but also in other beings, it is the most primitive of powers. This power has two fundamental duties. While its first duty is to serve the body through such actions as eating and drinking, its second duty is to ensure human development and continuation of the species. This power benefits man through providing the required energy for reproduction and to develop the physical body (Cheraghi, 2012; Haque, 2004).

This inclination is criticized not from an existential perspective but because it is both insatiable and selfish (Ghazzâlî, trans. 1994). When the emotion of lust is not controlled by the faculty of reason through various precautionary measures, it not only leads a person to undertake harmful actions and distressful occupations, it also affects other inclinations, taking them under its control and managing how they behave (Shah, 2015). Human beings, then, exhibit an extreme propensity to food and sex, similar to that of animals (Ghazzâlî, trans. 1994). Ghazzâlî informs us that man's first sin was eating from the forbidden tree in the story of Adam and Eve, a sin that stemmed from man's desire to satisfy the wants of his stomach (Shah, 2015). The sexual instinct can be shown to be the cause of such ailments as sexual dysfunction and disorders, sexual perversions, addictions, and eating disorders as well as characteristics of hedonism (Cheraghi, 2012), greed, stinginess, and extravagance (Gianotti, 2011).

Ghazzâlî asserts that an unchecked inclination of lust forces man to exert all of his energy only to satisfy his biological needs, stating moreover that an unrestrained inclination of lust weakens man's ability to reason. Unchecked by the faculty of reason, Ghazzâlî holds that this powerful inclination oppresses the individual and weakens his self-control, forcing him to act in such a way that he seeks only to satisfy his own personal desires and hindering him from involving himself in occupations truly beneficial to himself and his community (Ghazzâlî, trans. 2000).

Ghazzâli informs us that when the powers of lust are completely done away with, order in the world may break down and that the interactions and relations (AR: mu âmalât) ${ }^{20}$ between people may disappear (Korlaelçi, 2012).

According to Ghazzâlî, when a person's faculty of reason controls his lusts, that person is able to reach such states of satisfaction, peace of mind and soul, elegance, and material prudence (AR: qanâ'ah) in addition to moderation in his sexual life and

$20 \mathrm{Mu}$ 'âmalât (Arabic): Rules such as marriage, inheritance, and trade regulating interpersonal relations. See DİA (Diyanet Islam Encyclopedia). 
powerful self-discipline (Ghazzâlî, trans. 1994; 2000). Since the inclination of lust is the most powerful and severe of all man's powers (Korlaelçi, 2012), it is more difficult to control it and bring it to a neutralized state than the other impulses.

\section{Predation/Anger Inclination}

Ghazzâlî accepts anger (AR: ğaḍab) as the second inclination found in man's nature (see footnote 4). Both the inclinations of anger and lust are found in the heart and are two powers that work to help the heart (Haque, 2004). As a result of this specific power, man is able to satisfy his fundamental need for security and protection (Ghazzâlî, trans. 1994).

Ghazzâlî states that an extreme level of anger can lead a person to dangerous places. Specifically, when one is under the influence of anger, he may exhibit emotions of enmity, vindictiveness, and hatred as well as such behaviors as aggressiveness, arguing, tyranny, and murder (Awang et al., 2014; Gianotti, 2011). Furthermore, this emotion of anger can cause a person to incline toward self-punishment and selfflagellation.

According to Ghazzâlî, when this power is subject to the reason's control in a balanced manner, the possessor of the anger will be just as collected, striving, protective, decisive, and brave as he is sweet-tempered, patient, and merciful (Shah, 2015). When the power of anger is below normal, its owner becomes extremely careless and cowardly (Cheraghi, 2012).

According to Ghazzâlî, this power sometimes unites with lust, raising the banner of rebellion against the heart and taking it under their control as a slave. In this case, since like lust, when anger is uncontrolled by the faculty of reason, it causes him harm; his heart is unable to find peace and his spiritual journey is held back. When the heart finds itself in such a predicament, it must seek help from the soldiers of knowledge and willpower in the reason's army, as these two soldiers have been prepared to fight against anger and lust. Otherwise, anger and lust will continue to strengthen and, in an attempt to satisfy themselves, take over and enslave the faculty of reason (Ghazzâlî, trans. 2000). Ghazzâlî uses symbolic language to describe the relation between the powers of anger and lust and the faculty of reason.

The faculty of reason may be likened to a hunter on horseback. The power of lust is like the horse, and the power of anger is like his dog. In this regard, whenever the horseman is a master and both his horse and dog well-trained, the circumstances are appropriate for the horseman to be victorious. If however, the horseman is incapable, his horse rebellious, and his dog hunts for itself, neither does the horseman have an obedient horse that will run on his command, nor does he have a dog that will chase after prey at his signal. Such a horseman in this regard is more likely to perish than to catch the prey after which he 
is chasing. The horseman's incompetence is an example of man's incompetence, lack of insight, and ignorance. The horse's rebelliousness is an example of both sexual desires and the stomach having supremacy. The dog hunting to satiate itself, however, is an example of anger having dominion over a person and completely overwhelming him (Ghazzâlî, trans. 1994, p. 2183).

Describing the relationship between the faculty of reason and the inclinations of anger and lust in this simile, Ghazzâlî asserts in the event that both lust and anger are trained, they may contribute to a person reaching his created human perfection (AR: takâmul). Furthermore, just as he explains in the above example, when these two inclinations are left free without any control, a person is weakened spiritually; he warns in another metaphor that he gives in Kimiya-i Sa' $a d a h$ (trans. 2000, p. 19) that one should not attempt to repress or annihilate these inclinations:

The heart is the sultan of the country, which is the body. The hands, feet, and other organs are his servants. The faculty of reason is his vizier, lust is his minister of finances, and anger is his minister of security. The powers in the front side of the brain compose his chief of intelligence. All news is collected in the brain and is presented to the vizier (reason). Based on the news received, the vizier takes precautionary measures and makes preparations for the sultan's expedition. If lust, anger, and other faculties revolt against the sultan, if they do not obey him, and if they block the roads to him, one's reason will busy itself with struggling against them to discipline them. The reason does not want to kill them because the country cannot be ruled without them. The precautionary measures taken here are to force them to obey so that in a future expedition they will be friends and helpers instead of enemies, thieves, and highwaymen. If they act as friends and helpers, the person is happy and peaceful.

\section{Lordly Inclination}

The third inclination giving direct to human behaviors is the lordly (AR: rabbâniyyah) power (see footnote 1). Ghazzâlî gives several verses from the Qur'ân as evidence that man has a lordly inclination in him (Janssens, 2011). While the powers of lust and anger exist in both human beings and animals, it the power of lordliness that separates man from animals (Ghazzâlî, trans. 1994). According to Ghazzâlî, a person under the influence of his lordly inclination pushes him to act in an arbitrary and oppressive manner in all of his affairs, desiring that he, and he alone, have the final word while rejecting any other's interference in his management of affairs (Shah, 2015). The power of lordliness causes a person to pretend that he is superior to all others, to refrain from being humble, and to see himself as having the most knowledge and skills (Korlaelçi, 2012).

A person directed by lordly impulses wants to have authority and power over others, chasing vanity, sanctimony (AR: riyâ), pleasure, and luxury throughout his life. If he is a scholar, he desires to learn all fields of knowledge, in an attempt to prove that he 
is superior to others by dent of his excessive knowledge and information. Since such people chase after praise and fame, the feel pride (AR: ğurûr) when it is said to them that they are processors of knowledge, whereas they feel sorrow and discontent when they are told to be unknowledgable (Cheraghi, 2012). Here Ghazzâlî again indicates that such feelings of jealousy, disdain, and selfishness also stem from the feeling of arrogance (Shah, 2015), asserting that these feelings not only serve no other purpose than to tire and busy people with pointless endeavors, but they also disrupt happiness and hinder spiritual development (Ghazzâlî, trans. 2007). According to him, these thoughts and states lead both himself and others to experience spiritual malaise, causing him to adopt a blinding ambition in which he is always comparing himself with others (Gianotti, 2011).

Just as self-love in a person can become excessive, it can also be so reduced that a person does not know the value of his existence. When self-love becomes excessive, it is called arrogance (AR: takabbur), whereas when it is becomes excessively scarce, its possessor is considered to lack self-confidence or to have an inferiority complex (AR: dillah). Those who do not have this power are not aware of the value of their existence and constantly elevate others in an attempt to cause the others to love them. Ghazzâlî gives the following example to explain this situation (trans. 1994).

"A scholar who stands up when his shoe repairman enters and gives him his seat while showing him extreme respect is equivalent to him disregarding the value of his knowledge and not giving himself his proper due. This is the meaning of despicableness (AR: dillah)" (p. 3242).

Ghazzâlî states that the lordly inclination can accept its boundaries as a result of being disciplined by the faculty of reason. He further asserts that when this inclination is balanced, a person not only acts justly in giving others value and in knowing his own value (Ghazzâlî, trans. 1994) and is also prudent and thankful, able to practice empathy, and guides others by helping them to reach their distinguished human virtues and qualities (Gianotti, 2011).

While examining human psychological disorders, Ghazzâlî includes those spiritual malaizes that stem from the lordly inclination (Derin, 2012). It is understood that this power of lordliness has a role in the very foundation of many scientifically identified personality disorders, including narcissism, addiction, obsession, and the need to gain attention, as well as such emotions causing such behavioral disorders as an inferiority complex or striving for superiority. Furthermore, it is accepted that those who damage the preference and decision-making mechanism of the people with whom they frequently interact by completely disregarding their adult ego end up causing serious psychological disorders in the people with whom they interact, beginning with family members and extending to more distant relations (Öztürk, 2004). 
When looked at from a socio-cultural context, people and societies under the control of their lordly inclinations are easily molded and brought to a dependent state through the dominant culture's use of a variety of forces that they use to impose their culture on them. A variety of communal and social conflicts, injustices, and oppressions in our world stem from people seeing themselves as superior in either an individual or collective sense. These sicknesses of the heart result in people abandoning themselves to unhappiness, pessimism, hopelessness, and pain (Shah, 2015).

\section{Satanic Inclination}

According to Ghazzâlî, the fourth and final power that directs man's behaviors is craftiness (see footnote 2). Using the satanic (AR: šayțâniyyah) attribute, people are able to show reality as different from what it really is (Umaruddin, 2003). A person under the influence of this power is able to manipulate those around him in order to attain his own interests. To reach his goal, a person searches out ways to deceive others and uses his faculty of reason for deceptive purposes (Gianotti, 2011). When this power unites with the other powers and splits off from reason's sovereignty, a person presents false information, masquerades as something he is not, and deceives others to achieve his goals (Derin, 2012). In explaining the satanic inclination in Kimiya-i Sa 'âdah (trans. 2000), Ghazzâlî calls this power devilry and states that its duty is to trick and deceive people. He furthermore mentions that conflicts in society as well as thoughts and actions causing spiritual malaise manifest as a result of a person's acting under the influence of his satanic inclination.

In Ihya'u 'Ulûmi'd-dîn (trans. 1994), Ghazzâlî states that it is the faculty of reason's duty to discover and discern the tricks of the satanic inclination. When this power's deceptive aspect is disciplined by the by the faculty of reason (Umaruddin, 2003), what is left are practical intelligence, ability, the power to control events, deep comprehension, and discerning insight that may be used for the benefit of the person (Ghazzâlî, trans. 2000). Ghazzâlî does, however, state that without this power, man is but an idiot (AR: aḥmâq) (Ghazzâlî, trans. 1994).

\section{Anxiety of the Heart}

Ghazzâlî states that the four aforementioned inclinations more often come together to exert influence over a person instead of acting single-handedly. He informs us that if any one of these inclinations is not under the control of person's faculty of reason, the other inclinations may easily affect that person's heart, resulting in its coming under even greater bondage (Ghazzâlî, trans. 1994). Ghazzâlî also informs us that although these inclinations can never be annihilated, they can be brought into submission and transformed through the use of the power of discernment (AR: muhâkamah), 
cognitive (AR: idrâk) and interpretive abilities, true knowledge, various spiritual (AR: ma'nawî) and psychological interventions, and strong willpower (Haque \& Keshavarzi, 2014).

According to Ghazzâlî, while man's power of lust leads him to excess, it is his satanic power that actually stimulates and incites both his power of lust and anger inclination. Whatever these attributes desire, they unite against the heart, forcing it to submit to and serve them. During all of this infighting, the heart's vizier (faculty of reason) must work with vigilance and deep insight to expose the satanic effect in order to undo the deception it has caused (Umaruddin, 2003). If this vizier is able to defeat lust and anger, the country's (the body) affairs return to order and justice begins to appear. If, however, the power of reason is unable to defeat lust and anger, the two overcome reason and together with the satanic power, take control of the country's willpower. In such a case, the satanic power resorts to every possible avenue to satisfy its lusts and to delight the power of anger, rendering the person a servant working solely to satisfy his own lusts and anger. In short, when one of these powers overcomes the weak faculty of reason, it causes the other powers to fall under its influence. A number of these powers unite and begin to influence a person's thoughts, ideas, and behaviors (Ghazzâlî, trans. 1994).

According to Ghazzâlî, a variety of psychological disturbances and behavioral disorders may manifest as a result of the intense pressure and tension caused by subconscious conflicts in a person. In one sense, this intense conflict turns into a state of anxiety stemming the gap between the strong desire in his created human nature (AR: fițrah) to reach his ideal state (AR: hâl) and his current state. Ghazzâlî informs us that this state of anxiety may be reduced through education and discipline in proportion to the degree that the gap between these two states is closed (Haque \& Keshavarzi, 2014), explaining that most people are at this state (Ghazzâlî, trans. 1994). Freud states that since this subconscious conflict is without end and that people are therefore unable to reach true happiness, one must view the state of conflict as natural imperfection to reduce the pain one feels (Hutton, 1988). Recommending a number of discipline and education practices, Ghazzâlî, on the other hand, states that this conflict can indeed come to an end and that the sides can experience a state of satisfaction (AR: muṭma in) (Langgulung, 1991).

Ghazzâlî asserts that there is nothing closer to a person than he is himself and that it is necessary for a person to first strive to know himself on this path of spiritual (AR: ma nawî) development (Ames, 2013). He also states that it is impossible for a person who does not know himself to give meaning to others (Ames, 2013), warning that (Ghazzâlî, trans. 1994): 
"In this case, everyone must scrutinize his own behaviors. He must think as to why he stops, why he acts, why he speaks, and why he remains silent. If a man who sees the truth looks with an attentive eye is able to easily realize for what he is striving to achieve throughout his entire life" (p. 2185).

One of the frequently referred to concepts during the modern period is that of freedom; a free person is defined as one who makes decisions and behaves according to his own will and thoughts independent of all external influence. This definition of freedom, according to Ghazzâlî's own understanding of the same concept, is an extremely painful situation. Ghazzâlî explains that once a person's spiritual (AR: ma nawî) curtains have been lifted, ${ }^{21}$ he will see very clearly that the he is following the commands and prescriptions of the inclinations of the self (AR: nafsî). Thus, whenever a person wants anything from any of these inclinations, he will immediately draw up the most detailed of plans and brave the most difficult of difficulties to acquire what he wants (Ghazzâlî, trans. 1994). For this reason, Ghazzâlî explains that it is necessary for people to be freed from the authority of their own internal shackles/base instincts before rising up against the injustice and evil occurring in the external world. He is also of the opinion that it is only possible way for people's characters to begin the process of gaining positive traits to first work on these inclinations (Ames, 2013).

Similar to Ghazzâlî's epistemology, concept map, and view of education, his analyzes of man's nature and behaviors also contain a theological background founded within a specific tradition (Attaran, 2015). For this reason, the emotions and behaviors that the four fundamental inclinations explained by Ghazzâlî cause may be divided and evaluated as being good/evil or beneficial/unbeneficial (Aydınl1, 2000). Ghazzâlî explains that when the heart assumes control over these four powers, not only do balance and benevolence begin to manifest in the heart, so do highly developed powers of cognition (AR: idrâk) and discernment (AR: farâsah). Moreover, such attributes as tranquility, continence, responsibility, generosity, and elegance develop, which not only make it easier to control the lust and anger that exists in the heart, but that also have the power to bring the powers of lust and anger to moderation. It will also be possible to overcome the power of anger in the heart, causing this anger to transform into such emotions as perseverance, determination, forgiveness, mercy, bravery, and other similar emotions (Umaruddin, 2003).

Since the creator's position is at the center of Ghazzâlî's intellectual endeavors, the division of good and bad as well as beneficial and unbeneficial finds itself in a very central position in Ghazzâlî's thought. Expressing human beings' true happiness, this division is, according to him, based on religion (Ames, 2013).

21 Lifting of the spiritual (AR: ma nawî) curtain: Grof explains this experiment in Transpersonal Psychology as a "holotropic state of consciousness" (Özdoğan, 2011). 


\section{The Psychological Value of Ghazzâlî’s Contributions}

While following a specific framework of examination in this work, it is observed that the resources pertaining to Ghazzâlî's analysis on the nature of man benefit from contain important data. The most noteworthy of the conclusions made pertaining to the data is that the heart, as one of the accepted psychological dynamics forming man's spiritual (AR: ma'nawî) dimension, has a variety of functions as well as complementary subsystems and is able to expand its limits. This reminds us of Jung's definition of psyche (Mattoon, 2005). From the perspective that man's biological and psychological sides reflect a sensitive interaction, we see that man is home to a soul (AR: rûh), nafs, reason, and inclinations and that just as he has a side disposed to the physical world via his conscious functions, so too does he have a dimension disposed to the metaphysical world via his spiritual abilities. In Freud's theory, just as within the psyche there exists a conflicting relation between the id, ego, and superego (Hutton, 1988), so too does the dynamic interaction occurring in the heart's subsystems change, either voluntarily or involuntarily, the heart's characteristics thereby keeping it from remaining a static organ (Ansari, 1992). In psychoanalysitic theory, the psyche that has transcended personal experiences, people, and timeknown as the collective unconscious - can be interpreted as the spiritual (AR: rûhânî/ ğayb) realm opening onto the heart in Ghazzâlî’s theory (Skinner, 2010).

The fact that the relation between a person's realist aspect (his ego) and his id, with its uncontrolled, insistent, and illogical desires, was described by Ghazzâlî 800 years before the appearance of psychoanalysitic theory using metaphors regarding the relationship between reason and inclinations needs to be properly understood and discussed. It is possible to see the similarity in between the perspectives in the following quotation.

The relationships between the ego and id may be likened to a horse and its rider. The horse supplies its rider with the energy to travel in the direction he desires. In addition to this, the horse's power must be constantly controlled or guided. Otherwise, the horse may throw the rider to the ground (Schultz \& Schultz, 2007, p. 609).

According to Ghazzâlî, the relation that these four inclinations, which are themselves in a state of interaction with the soul/inner self (AR: rûh), have with reason affects each person differently depending on his ego consciousness level. The concept of nafsu'l-ammârah, when inclinations that are not subject to the reason's authority or control and the stage when the ego/nafs has only its weakest qualities at itself disposal (Othman, 2014) resembles the state where the id's makeup imposes itself on a person's conscience. Through the reason's control of the inclinations, the second level of ego consciousness (Skinner, 2010) is the nafsu'l-lawwâmah, at which the ego constantly criticizes, condemns, and punishes itself. During this stage, it may seem that a person's other fundamental organ, his superego, begins to interact and 
interfere with the person's ego. Since in Freud's environment personal background and career were primary areas of focus, he was unable to identify a third fundamental organ related to ego consciousness in his theory. Nafsu'l-mutma 'innah is the name given by Ghazzâlî at this third stage (Haque \& Keshavarzi, 2014; Langgulung, 1991), and according to Jung's understanding, it is at this stage that, with its balancing and regulatory role, the ego realizes its potential to send the essence of a person's characterthat person's self-on a journey to become an integrated individual (Schroeder, 1992). Ghazzâlî, in a similar vein, states that this spiritual journey (AR: sayru'l-sulûk) is possible under the direction of the inner self (AR: rûh).

Throughout the history of western psychology, many scientists have examined what Ghazzâli describes as the lordly (AR: rabbâniyyah) inclination with such concepts as striving for superiority, the inferiority complex (Adler, 2010), and narcissism (Freud, 2014), counting it as being among the fundamental symptoms of a number of psychological and personality disorders (American Psychiatric Association 2013, Öztürk, 2004). In his works, Ghazzâlî considered this superiority inclination to be just as valuable important in the struggle against hopelessness in human beings as he did the other inclinations, stating that it had a harmful side when unchecked and uncontrolled.

Modern psychology has yet to recognize an aspect of the mind similar to Ghazzâlî's satanic inclination. Yet, during our examinations of social life and observations of the human makeup, the effect of this inclination on relationships is at a noticeable level. In addition to observing such behaviors as lying, harming others, theft, and aggressiveness, which are both redundant and obstinate over the long term, a large number of psychological disturbances, such as antisocial personality disorder and conduct disorder in children (APA, 2013; Öztürk, 2004), are described in Ghazzâlî. Whether intellect (AR: dekâ) exists as an inclination within man's makeup in which a person is under the direction of such negative behaviors as deceit, lying, and slyness may be a further research subject. Ghazzâlî states that it is extremely difficult to separate the four inclinations in man's heart by looking at behaviors and that the intense pressure and tension resulting from the conflict is felt to varying degrees as anxiety and is lifelong.

\section{Conclusion}

Ghazzâlî is accepted as a thinker whose equal has rarely been seen throughout the entirety of Islamic religious and philosophical history (Griffel, 2009). Being educated by a variety of scholars of his era provided him with variety of ideas and allowed him to develop his mental framework as an analyst (Garden, 2014). This inquisitive attitude was augmented by his curiosity and desire to search for truth, and important works in a variety of fields began to appear. The theological platform 
as well as the personal views of the researchers examining him in the context of Islamic literature, together with certain works found in Ghazzâlî's oeuvre have caused him to be frequently considered within a religious studies framework. Yet the fact that Ghazzâlî's explanations and numerous discussions of human beings have maintained their relevance despite the passing of several centuries necessitate that Ghazzâlî's works be expounded upon in a more comprehensive and extensive manner by specialists in psychology.

We have observed that when psychological literature of the modern period (Freud, 2014; Jung, 2001) and Eastern/Islamic philosophical resources are examined (Ghazzâlî, 2000; Rüşd, 2004), there is a serious terminological disparity in the comparisons made in international publications (Ansari, 1992; Haque, 2004; Othman, 2016; Skinner, 2010), due not only to the fact that analyzes of the human makeup have used different names for concepts, but also that there is not an exact terminological equivalent for many, if not all of these concepts. This problem is also noticed in those sources examining and Ghazzâlî's works using a comparative approach. For this reason, researchers should transfer the meaning that Ghazzâlî attempted to express together with their original concepts and words when making recommendations and conclusions related to their field of expertize without separating Ghazzâlî's analyzes on man's nature and his spiritually oriented strategies related to the metaphysical world from their own context. In addition to this, we assert that from the perspective of scientific progress, doing so will render comparative analyzes more effective in expanding and understanding the resulting findings.

By evaluating Ghazzâlî's works from a psychological perspective, the shared subconscious values, way of perception, and both the psychological and the spiritual characteristics of an individual kneaded within a society formed from an rich cultural fabric with its own specific linguistic characteristics may be analyzed. Such an analysis of the quality of man's personality and its dimensions may lead to effective forms of treatment for psychological problems, a variety of models of education, as well as ways and methods of developing a person's personality in a holistic manner.

\section{References}

Adler, A. (2010). Understanding human nature: The psychology of personality. London, UK: One world Publications.

Akay, H. (2004). İslami terimler sözlüğ̈̈ [Dictionary of Islamic terms]. İstanbul, Turkey: İşaret Yayınları.

Akçay, M. (2005). Gazzali'de ruh tasavvuru [The imagination of spirit in Ghazali]. Dini Araştırmalar Dergisi, 7, 87-115.

American Psychiatric Association. (2013). Diagnostic and statistical manual of mental disorders (DSM-5). Arlington, Va: Author. 
Ames, R. L. (2013). The technology of happiness: Philosophy, the body, and Ghazali's Kimiya-yi Sa 'ada. Comparative Islamic Studies, 9, 121-139.

Ansari, Z. A. (1992), Qur'anic concepts of human psyche. Lahore, Pakistan: International Institute of Islamic Thought.

Attaran, M. (2015). Moral education, habituation, and divine assistance in view of Ghazali. Journal of Research on Christian Education, 24, 43-51.

Awang, R., Noor, S. S. M., Muhamad, N. H. N., Abdul-Rahim, R., Yusoff, K., Salamon, H., \& Nasir, B. M. (2014). Anger Management: A Psychotherapy Sufistic Approach. Research Journal of Biological Sciences, 9, 13-15.

Aydınlı, Y. (2000). Gazzali'nin düşünce dünyası [Gazali's science and thought world]. Íslami Araştırmalar Dergisi, 13, 265-281.

Azadpur, M. (2003). Unveiling the hidden: On the meditations of Descartes and Ghazzali. In A. T. Tymieniecka, (Ed.), The passions of the soul in the metamorphosis of becoming. Islamic philosophy and occidental phenomenology in dialogue. Dordrecht, Netherlands: Kluwer Academic Publishers. http://online.sfsu.edu/azad/Azadpur\%20Ghazali.pdf

Bolay, S. H. (2013). Aristo ve Gazzali metafizikleri [Metaphysics of Aristotle and Ghazzali]. Ankara: Nobel Yayın Dağıtım.

Çağrıcı, M. (1996). Gazzali [Al-Ghazzali]. In Turkish religious foundation İslamic Encyclopaedia (Vol.13, pp. 489-505). Ankara, Turkey: Türkiye Diyanet Vakfi.

Çağrıcı, M. (2013). Gazzali'ye göre İslam ahlak [Islamic morality according to Ghazzali]. İstanbul, Turkey: Ensar Yayıncilik.

Çamdibi, M. (2014). Şahsiyet terbiyesi ve Gazzali [Personality training and Ghazzali]. İstanbul, Turkey: Çamlıca Yayınları.

Cheraghi, A. (2012). Gazzali' psikolojisi ve modern psikolojinin ortak noktaları [Similar aspects of Ghazali's psychology and current psychology] Milletlerarası Tartısmalı Illmi Toplantı, 07-09 Ekim 2011 (Vol: 271, pp. 809-819). İstanbul, Turkey: Marmara Üniversitesi İlahiyat Fakültesi Vakfi Yayınları.

Corsini, R. J., \& Wedding, D. (2011). Current Psychotherapies. Belmont, CA: Brooks/cole, Cengage Learning.

Derin, S. (2012). Manevi psikoloji ve Gazzali [Spiritual psychology and Ghazzali]. Milletlerarası Tartışmalı İlmi Toplantı, 07-09 Ekim 2011 (Vol: 271, pp. 788-798). İstanbul, Turkey: Marmara Üniversitesi İlahiyat Fakültesi Vakfi Yayınları.

Erdem, H. (2012). Gazzali'de akıl bilgisi ve değeri [Al-Ghazzali's intellectual knowledge and its value]. Diyanet İlmi Dergisi, 47, 60-69.

Fahri, M. (2008). İslam felsefesi tarihi [History of Islamic philosophy] (K. Turhan, Trans.). İstanbul, Turkey: Şato Yayınevi.

Freud, S. (2014). On narcissism: An introduction. New York, NY: Read Books.

Garden, K. (2014). The first Islamic reviver: Abu Hamid al-Ghazali and his revival of the religious sciences. New York, NY: Oxford University Press.

Gazzâlî, (1994). İhya 'u Ulumi'd-din (A. Aydın, Trans.). İstanbul, Turkey: Aydın Yayınları.

Gazzali, (2000). Kimyâ-yı Saadet (A. Arslan, Trans.). İstanbul, Turkey: Merve Yayınları.

Gazzali, (2004). Ravdatü't Talibin ve Umdedü’s Salikin (D. Selvi, Trans.). İstanbul, Turkey: Semerkand Yayıncilik.

Gazzali, (2007). Minhacu'l Abidin (A. Kaya, Trans.). İstanbul, Turkey: Semerkand Yayınc1lık.

Gergen, K. J., \& Collage, S. (2001). Psychological science in a postmodern context. American Psycholocigal Assocation, 56, 803-813. 
Gianotti, T. J. (2011). Beyond both law and theology: An introduction to al-Ghazālì's "Science of the way of the afterlife" in reviving religious knowledge (Ihya'i Ulūm al-Din). The Muslim World, 101, 597-613.

Griffel, F. (2009). Al-Ghazali's philosophical theology. Oxford, UK: Oxford University Press.

Haque, A., \& Keshavarzi, H. (2014). Integrating indigenous healing methods in therapy: Muslim beliefs and practices. International Journal of Culture and Mental Health, 7, 297-314.

Haque, A., \& Mohamed, Y. (2009). Psychology of personality: Islamic perspectives. Kuala Lumpur, Malaysia: Cengage Learning Asia.

Haque, A. (2004). Psychology from Islamic perspective: Contributions of early Muslim scholars and challenges to contemporary Muslim psychologists. Journal of Religion and Health, 23, 366-368.

Hermansen, M. (2001). Dreams and dreaming in Islam. In Dreams (pp. 73-91). New York, NY: Palgrave Macmillan US.

Hozien, M. (2011). Ghazali and his early biographers. Islam \& Science, 9, 95-123.

Hutton, P. H. (1988). Foucault, freud, and the technologies of the self. In L.H. Martin \& M. H. Hutton (Eds.), In Technologies of the Self: A Seminar with Michel Foucault (pp. 121-144). Amherst, Massachusetts: University of Massachusetts https://monoskop.org/images/0/03/Technologies_of the_Self_A_Seminar_with_Michel_Foucault.pdf

İnam, A. (2000). Gazzali'nin kalp ordusu [Gazali’s heart arm]. İslami Araşttrmalar Dergisi, 13, 511-518.

Janssens, J. (2011). Al-Ghazali between Philosophy (Falsafa) and Sufism (Tasawwuf): His complex attitude in the marvels of the heart (Aca'ib al-kalb) of the Ihya' Ulūm al-Din. The Muslim World, $101,614-632$.

Jung, C. G. (2001). Modern man in search of a soul. Hove, East Sussex: Psychology Press.

Karaırmak, Ö. (2004). Tinsel anlayışın psikolojik danışmadaki rolü [Spiritual dimension on psychological counseling]. Türk Psikolojik Danışma ve Rehberlik Dergisi, 3, 45-53.

Korlaelçi, M. (2012). Gazzali'de insan anlayışı [Human nature in Ghazzali]. Milletlerarası Tartışmalı İlmi Toplantı, 07-09 Ekim 2011 (Vol: 271, pp. 760-786). İstanbul, Turkey: Marmara Üniversitesi İlahiyat Fakültesi Vakfi Yayınları.

Kukkonen, T. (2012). Receptive to reality: Al-Ghazali on the structure of the soul. The Muslim World, $102,541-561$.

Langgulung, H. (1991). İntegrated personality and integrated education: A psycho-socio-spiritual approach. Muslim Education Quarterly, 8, 37-46.

Langgulung, H. (2002). A Psycho-pedagogical approach to Islamization of knowledge. Kuala Lumpur, Malaysia: International Islamic University.

Mattoon, M. A. (2005). Jung and the human psyche: An understandable introduction. Oxford, MA: Taylor \& Francis.

Merter, M. (2014). Nefs psikolojisi [Nafs psychology]. İstanbul, Turkey: Kaknüs Yayınları.

Nakamura, K. (2001). Ghazali and Prayer. Kuala Lumpur: Islamic Book Trust. Retrieved January 26, 2017 from http://www.ghazali.org/2015/10/nakamura-2/

Orman, S. (2000). Gazzali'nin hayatı ve eserleri [Works and life of Ghazzali]. İslami Araştırmalar Dergisi, 13(3-4), 237-248.

Othman, N. (2014). A comparative study between Western and Islamic perspectives on human development and life-friendly environment. Dalam Journal of Research in Islamic Studies, 1, 6-28.

Othman, N. (2016). A preface to the Islamic personality psychology. International Journal of Psychological Studies, 8, 20-27.

Özdoğan, Ö. (2011). Gazzali ve ben ötesi yaklaşım [Ghazzali and transpersonal approach]. Ankara Üniversitesi İlahiyat Fakültesi Dergisi, 52, 5-19. 
Öztürk, O. (2004). Ruh sağllğı ve bozuklukları [Mental disorder]. Ankara, Turkey: Nobel Tip Kitapevi.

Parsons, W. B. (2013). Psikoloji: Din psikolojisi [Psychology: Psychology of religion] (M. Ulu, Trans.). Din Bilimleri Akademik Araştırma Dergisi, 13, 235-255.

Rüşd, İ. (2004). Metafizik şerhi [Metaphysical interpretation] (M. Macit, Trans.). İstanbul, Turkey: Litera Yayınları.

Schroeder, H. W. (1992, April). The spiritual aspect of nature: A perspective from depth psychology. In Proceedings of the 1991 Northeastern Recreation Research Symposium (pp. 25-30). G. Vander Stoep.

Schultz, D. P., \& Schultz, S. E. (2007). Modern Psikoloji Tarihi [A history of modern psychology] (Y. Aslay, Trans). İstanbul: Kaknüs Yayınları.

Shah, R. R. (2015). Saint Thomas Aquinas and Imam al-Ghazali on the attainment of happiness. The International Journal of Religion and Spirituality in Society, 6, 15-29.

Sherif, M. A. (1975). Ghazali's theory of virtue, studies in Islamic philosophy and science. New York, NY: The Society for the Study of Islamic Philosophy and Science.

Skinner, R. (2010). An Islamic approach to psychology and mental health. Mental Health, Religion \& Culture, 13, 547-551.

Uludağ, S. (2000). Bir düşünür olarak Gazzali [Al-Ghazzali as a thinker]. İslami Araştırmalar Dergisi, $13,249-254$.

Uludağ, S. (2002). Tasavvuf terimleri sözlüğü [Dictionary of Sufi terms]. İstanbul, Turkey: Kabalcı Yayınlar1.

Umaruddin, M. (2003). The ethical philosophy of al-Ghazzali. Kuala Lumpur, Malaysia: A. S. Noordeen.

Watt, W. M. (1963). Muslim intellectual: A study of al-Ghazali. Edinburg, UK: Edinburg University Press.

Watt, W. M. (2000). The Faith and Practice of Al-Ghazali. London: England: Oneworld Publication. Retrieved January 22, 2017 from http://www.amazon.com/Practice-Al-Ghazali-Oneworld-ClassicsReligious/dp/1851680624

Yıldırım, A., \& Şimşek, H. (2011). Sosyal bilimlerde nitel araştırma yöntemleri [Qualitative research methods in the social sciences]. Ankara, Turkey: Seçkin Yayıncılık. 